\title{
31. Nuclear-Powered Cardiac Pacemakers
}

\author{
R L Shoup
}

The cardiac pacemaker is the first prosthetic device powered by nuclear energy to achieve practical application in man Several manufacturers have developed ${ }^{238} \mathrm{Pu}$-powered pacemakers Since plutonium is, by definttion, "special nuclear material," pacemakers contaming ${ }^{238} \mathrm{Pu}$ are subject to Nuclear Regulatory Commission (NRC) regulations in Title 10, Code of Federal Regulations, Part 70 (10 CFR 70) Prior to licensing plutonium-powered pacemakers for routine use, the NRC is required to write an environmental statement discussing aspects of their impact on the environment This program in the Health Physics Division of ORNL is to provide NRC with technical assistance in completing this environmental assessment This assistance primarily includes performing an environmental risk assessment and a benefit analysis

\section{BACKGROUND}

Several tens of thousands of cardiac patients in the United States have been restored to normal and useful lives with the implantation of cardiac pacemakers Pacemaker implantations are indicated for patients suffering from certain forms of cardiac arrhythmias In most cases, these disturbances are associated with a lack of effective, coordinated contraction of the heart's lower chamber in synchrony with its upper chambers

Conventional pacemakers are powered by mercury batteries (mercuric oxide-zinc) and require periodic surgical replacement of the entıre pacemaker upon the loss, or impending loss, of battery output The present expected service lifetıme of conventional paceınakers including new improved batteries ranges from $1 \frac{1}{2}$ to 6 years (service lifetimes based on the period of time the manufacturer will grarantee the unit) A rechargeable pacemaker using a nickel-cadmium battery has recently been developed with a lifetime of 10 years The expected lifetımes of plutonium-powered cardiac pacemakers range from 10 to 20 years
The NRC is currently licensing the implantation of plutonium-powered pacemakers under a limited invest1. gational program untıl it can be established that (1) nuclear-powered pacemakers are safe and reliable, (2) routine use will not subject the public to any undue risk, and (3) the benefits derived from the use of nuclear-powered units will outweigh the risk to the public

Pursuant to NRC's responsibilities under the National Environmental Policy Act of 1969 (Public Law 91-190), the Council of Environmental Quality's guidelines of August 1, 1973 (38 F R 20550), and 10 CFR 51 of the Commission's regulations, environmental statements are required to be prepared pror to taking major Federal actions that may affect the quality of the human environment Authorizing the routine use of nuclear-powered pacemakers (beyond the present investigational use) is considered to be a major Federal action Therefore, an environmental statement has been written which describes and evaluates the environmental consequences of use of plutoniun fuel in cardiac pacemakers

Three major subjects are identified from the $10 \mathrm{CFR}$ 51 guidelines as being pertinent to this environmental statement These are (1) potential impacts on the environment, (2) a cost-benefit and benefit-risk balance, and (3) avalable alternatives to such use With respect to environmental impacts, three are identified (1) radiation exposure to the patients from implanted pacemakers, (2) exposure to the public from normal use, and (3) release of plutonium from accidental or abnormal events

\section{ENVIRONMENTAL ASSESSMENT}

The radiation doses from a Medtronics model 9000 pulse generator containing $1732 \mathrm{mg}$ of plutonium of $90 \%$ by weight ${ }^{238} \mathrm{Pu}$ and $026 \mathrm{ppm}{ }^{236} \mathrm{Pu}$ were determined by Battelle Pacific Northwest Labora- 
tories. $^{1}$ Integrated total dose equivalents to various organs for 5-, 10-, 15-, and 20-year periods are shown in Table 31.1 for a subcutaneous pacemaker implant above the left pectoral muscle (implant location shown in Fig. 31.1).

The radiation level at the skin surface of a patient with an implanted pacemaker is 1 to 2 millirems/hr, and at a distance of $20 \mathrm{~cm}$ from a patient's body the radiation from a pacemaker is less than the ambient background radiation.

Spouses of pacemaker patients will receive the largest radiation exposure. This is because their contact with the patients is more frequent and at closer distances than contacts by other persons. The average annual exposure to a spouse from a patient was calculated by Battelle Pacific Northwest Laboratories to be 5 to 15 millirems/year, ${ }^{2}$ and most of this exposure is received during the sleeping hours, when the spouse is usually within a few feet of the patient.

All other individuals associating with pacemaker patients will be exposed to much lower levels of radiation. Dose calculations for various categories of people with whom pacemaker patients are likely to come into contact during their daily activities are

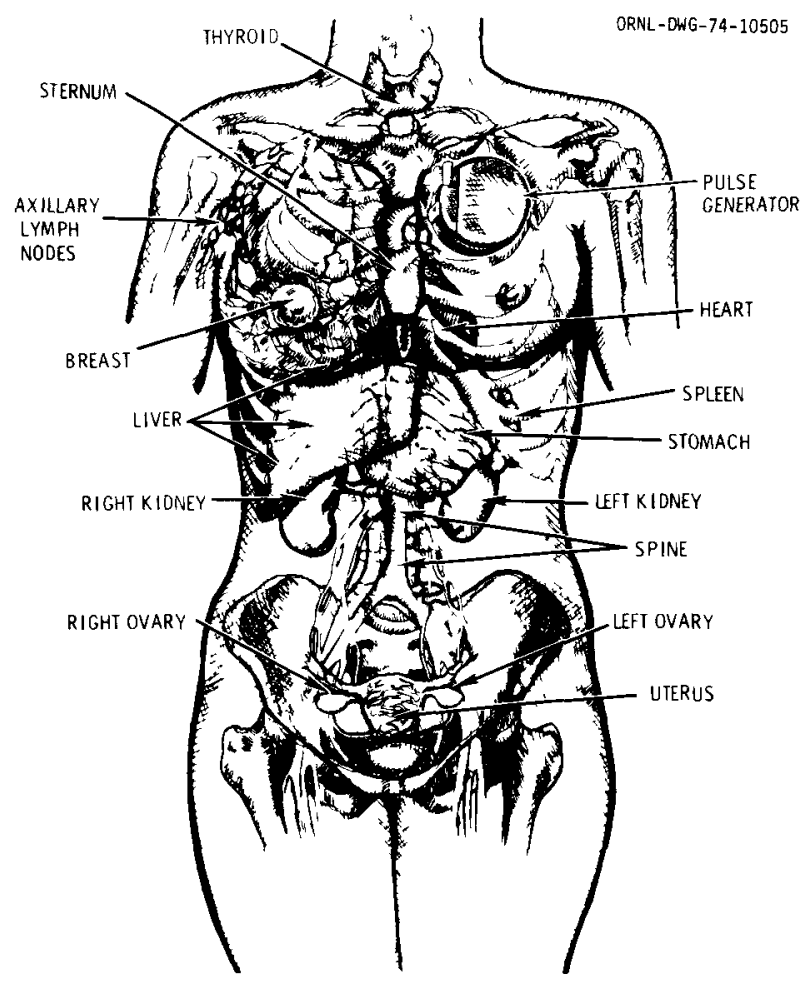

Fig. 31.1. Location for normal implantation of a pacemaker above left (or right) pectoral muscle. shown in Table 31.2. With respect to the general public, the radiation dose attributable to pacemaker patients will be negligible.

Pacemakers are required to be designed to high standards such that they can withstand hypothetical credible accidents. Also, requirements are placed on the fuel form to assure that its physical and chemical form be such that it will be as nondispersible and nontransportable as is practicable. Plutonium dioxide, a chemically unreactive form of plutonium, is compressed and fired into a hard, glossy ceramic pellet to reduce the likelihood of wide-scale fuel dispersion in the event of an accidental capsule breach. To provide a high degree of assurance that the plutonium fuel will be contained under any accident condition, the fuel pellets are clad with two or three layers of refractory metals. Manufacturers are required to demonstrate that their pacemaker model will be able to maintain fuel capsule integrity over a spectrum of mechanical, thermal, and environmental stresses.

The possibility that stresses may be sufficient to breach the fuel capsule does exist. For this reason, a risk assessment of credible events and their probability of occurrence was performed. A probabilistic model was developed to establish probabilities of and potential hazards from a capsule breach. A block diagram of this analysis is shown in Fig. 31.2.

Radiological consequences are calculated by combining accident statistics from mortality tables with probabilities of capsule breach by different stresses and source-term information in the event of a breach.

The cremation of a deceased patient's body with his pacemaker still intact is deemed to be the most likely incident to result in the dispersion of plutonium fines into the environment. The probability of a pacemaker's fuel capsule rupturing in a crematory furnace is dependent upon a number of factors. These are the probability of a patient death per year, the probability of a body being cremated after death, the probability that the pacemaker will not be removed prior to cremation, and the probability that the cremation furnace may exceed the prototype test temperature for a sufficiently long time to rupture the fuel capsule. These four probabilities combine to an overall expecta-

1. L. W. Brackenbush, G. W. R. Endres, and B. I. Griffin, "Radiation Doses from the Medtronic Laurens-Alcatel Model 9000 Pulse Generator," Battelle Pacific Northwest Laboratories Report 2211201653 , Amendment 2 (October 1973).

2. R. W. McKee, L. C. Clark, B. M. Cole, and R. A. Libby, "Dose to the Population: Estimates for Use of Radioisotope Powered Cardiac Pacemakers," BNWL-1858 (draft) Battelle Pacific Northwest Laboratories (September 1974). 
Table 31.1. Integrated dose equivalents to organs for 5-, 10-, 15-, and 20-year periods

Pulse generator above left pectoral muscle

\begin{tabular}{|c|c|c|c|c|}
\hline \multirow{2}{*}{$\begin{array}{l}\text { Organ } \\
\text { location }\end{array}$} & \multicolumn{4}{|c|}{$\begin{array}{l}\text { Integrated dose equivalent, } \\
\text { neutron and gamma (rems) }\end{array}$} \\
\hline & 5 years & 10 years & 15 years & 20 years \\
\hline Thyrold & 2.7 & 55 & 8.9 & 12 \\
\hline $\begin{array}{l}\text { Left axillary } \\
\text { lymph nodes }\end{array}$ & 2.4 & 5.1 & 8.1 & 11 \\
\hline $\begin{array}{l}\text { Right axillary } \\
\text { lymph nodes }\end{array}$ & 0.33 & 0.88 & 1.2 & 1.7 \\
\hline Sternum & 2.3 & 47 & 7.8 & 10 \\
\hline $\begin{array}{l}\text { Left pectoral muscle } \\
\text { (base of breast) }\end{array}$ & 0.76 & 1.8 & 2.7 & 3.6 \\
\hline $\begin{array}{l}\text { Right pectoral muscle } \\
\text { (base of breast) }\end{array}$ & 031 & 082 & 1.2 & 17 \\
\hline Heart & 0.70 & 1.7 & 2.5 & 32 \\
\hline Liver & 023 & 0.64 & 0.97 & 14 \\
\hline Spleen & 0.30 & 1.3 & 19 & 2.4 \\
\hline Stomach & 029 & 0.80 & 1.2 & 16 \\
\hline Left kıdney & 0.20 & 052 & 081 & 1.2 \\
\hline Right kidney & 0.19 & 0.48 & 0.75 & 11 \\
\hline Left ovary & 0.11 & 0.25 & 0.41 & 060 \\
\hline Right ovary & 011 & 024 & 040 & 0.58 \\
\hline Uterus & 010 & 023 & 0.38 & 054 \\
\hline Testes & 009 & 020 & 032 & 0.43 \\
\hline Spıne (average) & 070 & 1.6 & 24 & 33 \\
\hline Torso (average) & 070 & 1.7 & 2.5 & 3.3 \\
\hline Whole body (average) & 0.36 & 0.95 & 1.3 & 1.8 \\
\hline
\end{tabular}

Table 31.2. Radiation doses to critical groups from cardiac pacemakers

Assuming 10,000 implanted cardiac pacemakers with plutonıum batteries

\begin{tabular}{|c|c|c|c|c|c|c|}
\hline \multirow[b]{3}{*}{ Critical group } & \multirow{3}{*}{$\begin{array}{c}\text { Group } \\
\text { population }\end{array}$} & \multicolumn{3}{|c|}{ Individual dose (millurems per person per year) } & \multirow{2}{*}{\multicolumn{2}{|c|}{$\begin{array}{l}\text { Total dose to group } \\
\text { (man-rems/year) }\end{array}$}} \\
\hline & & \multirow[b]{2}{*}{$\begin{array}{l}\text { Dose from } \\
\text { pacemaker }^{a}\end{array}$} & \multicolumn{2}{|c|}{ Average dose } & & \\
\hline & & & $\begin{array}{l}\text { Medical } \\
\text { X rays }\end{array}$ & $\begin{array}{l}\text { Natural } \\
\text { background } \\
\text { radiation }\end{array}$ & $\begin{array}{c}\text { Dose from } \\
\text { pacemaker } b\end{array}$ & $\begin{array}{c}\text { Natural } \\
\text { background } \\
\text { radiation }\end{array}$ \\
\hline Spouses & 6,340 & $6-15$ & 73 & 102 & 84 & 646 \\
\hline Household members & 8,950 & $1-3$ & 73 & 102 & 24 & 912 \\
\hline Work associates $^{c}$ & 72,000 & $0.1-03$ & 73 & 102 & 21 & 7,344 \\
\hline Nonwork associates $^{c}$ & 218,000 & $005-0.15$ & 73 & 102 & 29 & 22,378 \\
\hline $\begin{array}{c}\text { Total in U.S. populace } \\
\text { not included above }\end{array}$ & & $\ll 001$ & 73 & 102 & $\begin{array}{r}98 \\
\end{array}$ & $21,400,000$ \\
\hline Total $^{d}$ & & & & & 256 & \\
\hline
\end{tabular}

${ }^{a}$ Dose will vary depending upon the plutonium content and fuel characteristics of a particular pacemaker model.

${ }^{b}$ Integrated dose using $8 \mathrm{C}$ of plutonium, which is maximum plutonium used in any battery.

${ }^{c}$ A pdtient is predicted to associate with approximately 30 persons during his dally activities

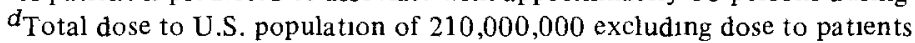




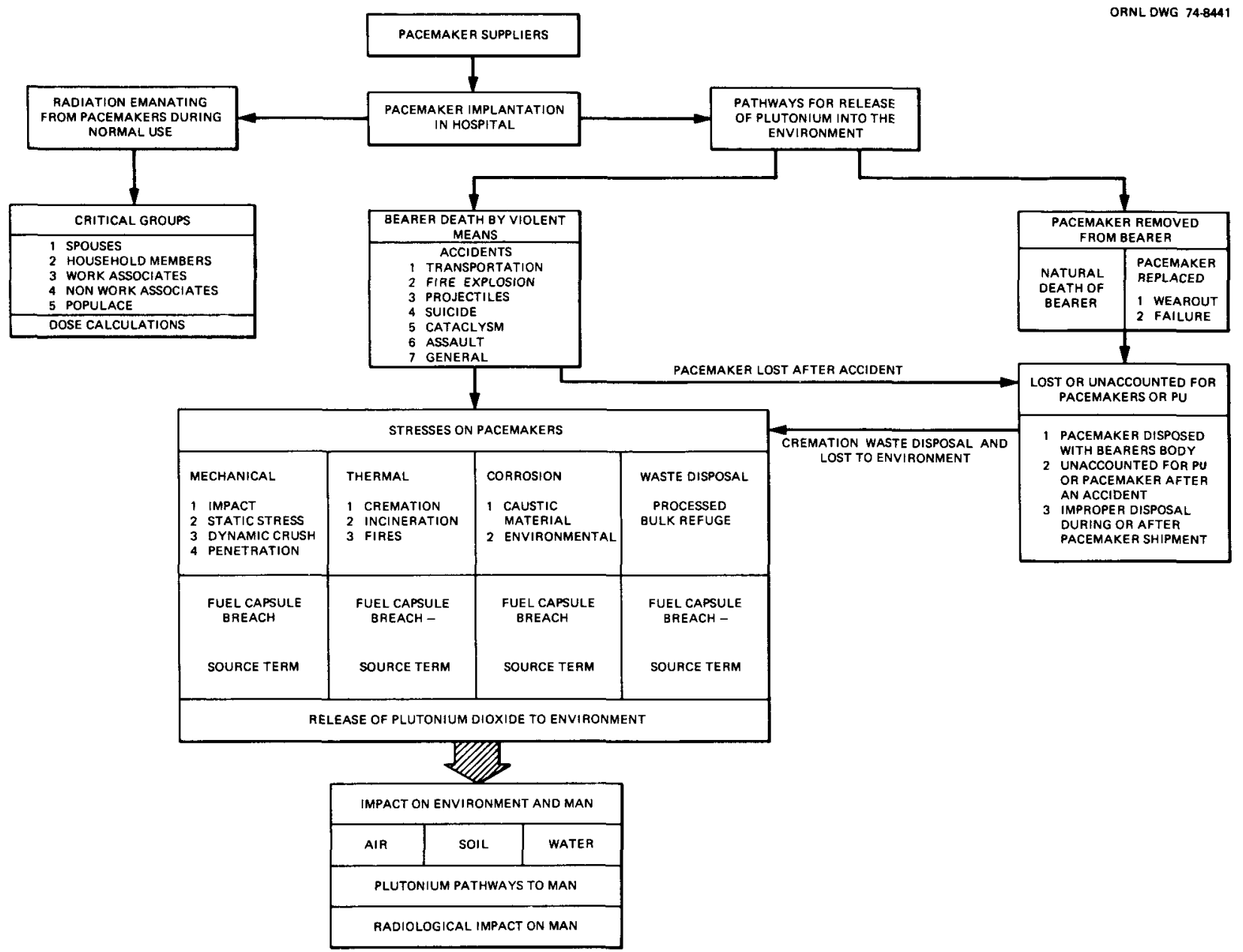

Fig. 31.2. Plutonium-powered cardıac pacemaker risk logic model.

tion of one breach in 20 years from a pacemaker population of 10,000 patients Figure 313 shows the risk-logic progression for a fuel-capsule breach durıng cremation

If a fuel capsule were to be breached in a crematory furnace, most of any plutonıum fines would remain in the retort or entrainment system of the furnace By assuming that all of the respirable size particles $(\leqslant 10$ $\mu \mathrm{m}$ from source-term information) leave the furance stack, the maxımum dose commitment to an individual in the vicinity of a crematonum is calculated to be 420 millirems (50-year dose commitment) The average 50-year dose commitment to individuals exposed to plutonium particles in the gaseous plume out to $2000 \mathrm{~m}$ from a crematorium is 75 millirems

These dose commitments are calculated from a computer code given settling velocities and release rate of plutonium fines Near neutral weather stability and a
$4 \mathrm{~m} / \mathrm{sec}$ wind velocity are used in the calculation, for they are reasonably representative of average US meteorological conditions The inhalation model employed to calculate absorbed dose is a representation of the lung model developed by the International Commission on Radiological Protection Task Group on Lung Dynamics The results of these calculations are shown in Fig 314 Data from Fig 314 on individual dose commitments are combined with data on population densities to calculate the total radiological impact within the area of the plume An average metropolitan population density (1760 per sons $/ \mathrm{km}^{2}$ ) is chosen as representative of population densities of cities in which crematoria are located The total 50 year dose commitment to an average metro politan population exposed in the downwind sector from a crematorium out to a radius of $20,000 \mathrm{~m}$ is 410 man-rems per postulated breach The population in 


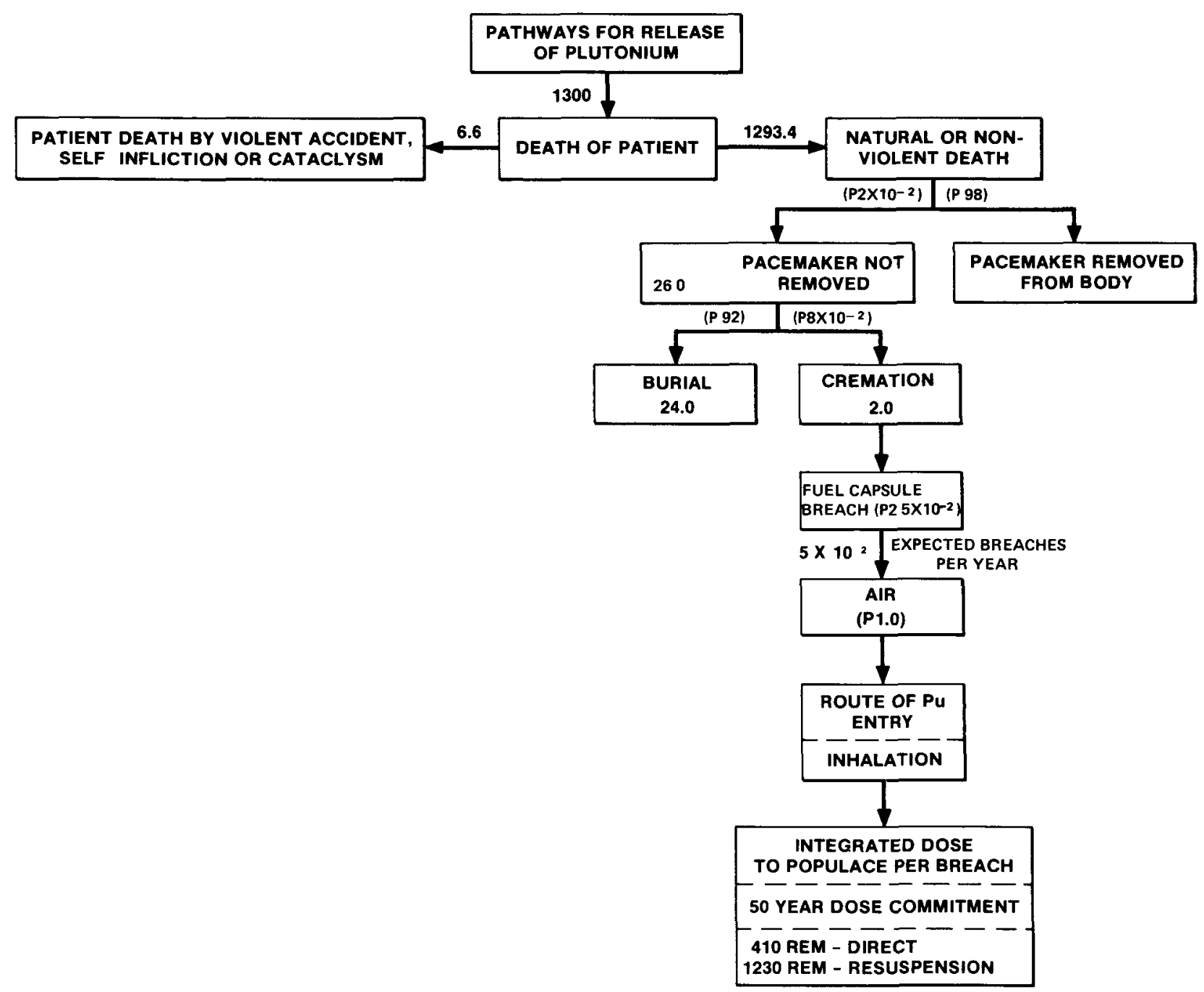

Fig. 31.3. Risk logic for a postulated fuel capsule breach during crematıon.

such a sector is 4500 persons, which is approximately $0002 \%$ of the US population The dose commitment over 50 years to this group of 4500 persons from a breach would be approximately $2 \%$ of their ambient background absorbed dose

\section{BENEFIT ASSESSMENT}

The benefits that can be realized from the use of plutonium-powered cardiac pacemakers are related to the long lifetıme of the plutonum-powered battery, which results in the reduction or elimination of the need for pacemakers to be replaced because of battery depletion The principal benefit derived from the use of plutonium-powered pacemakers is the number of lives saved by the decreased surgical mortality associated with decreased need for replacement operations, the attendant reduction in surgical and medical complications, and the reduction of patient pain, suffering, and anxiety

Mortalities from surgical procedures including post. operative follow-up vary from 1 to $4 \%$, with a mean value of approximately $3 \%$ A surgical mortality rate of $1 \%$ is used for reimplantation operations because they involve a reduced risk due to simpler procedures (More recent statistics indicate that these mortalities are much lower )

These mortality rates were used in a computer program which was developed to compare expected patient mortalities for groups of patients using various 
Table 31 3. Surgical deaths per 10,000 pacemaker patients (equilibrium patient population size) wearing pacemakers with vanous replacement (service life) intervals

\begin{tabular}{ccrrrrr}
\hline \multirow{2}{*}{$\begin{array}{c}\text { At end } \\
\text { of year - }\end{array}$} & \multicolumn{5}{c}{ Deaths per 10,000 patients for pacemaker replacement interval of - } \\
\cline { 2 - 7 } & $1 \frac{1}{2}-3$ years & 5 years & 6 years & 8 years & 10 years & 20 years \\
\hline 5 & 665 & 528 & 500 & 489 & 489 & 489 \\
10 & 1100 & 822 & 785 & 750 & 727 & 712 \\
15 & 1545 & 1118 & 1066 & 1002 & 973 & 938 \\
20 & 1980 & 1413 & 1342 & 1260 & 1218 & 1162 \\
\hline
\end{tabular}

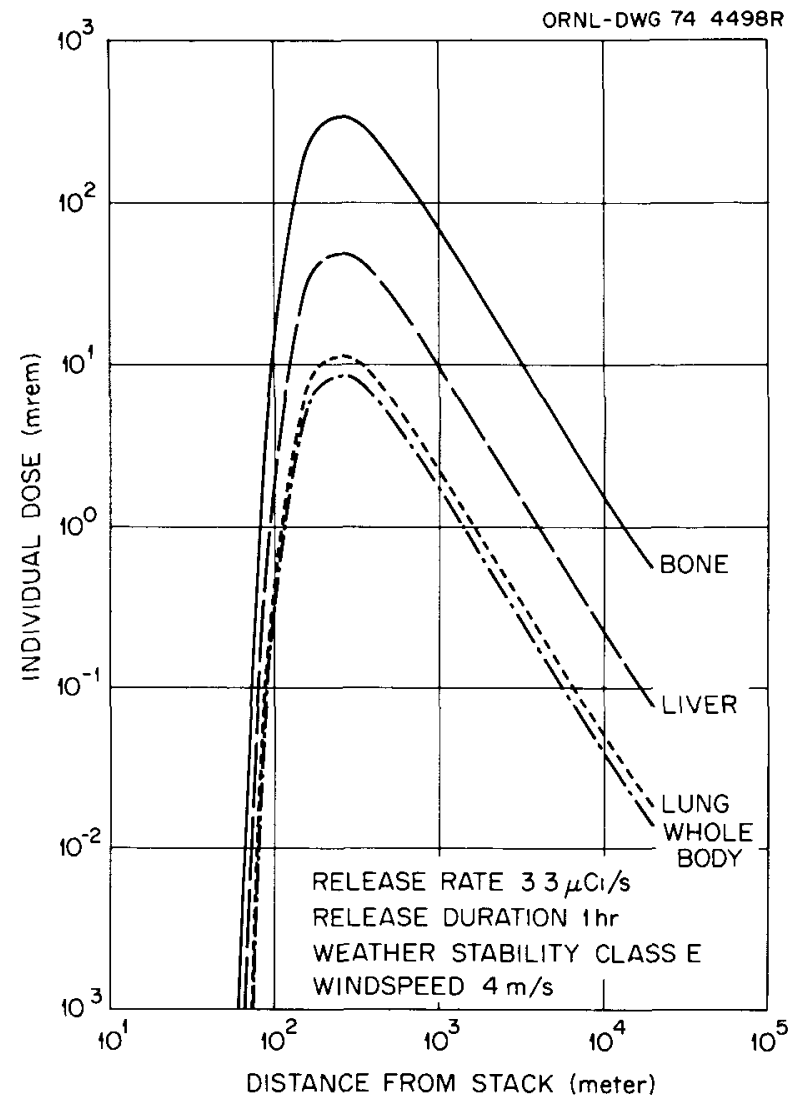

Fig. 31.4. Dose for ${ }^{238} \mathrm{PuO}_{2}$ particle size $\leqslant 10 \mu \mathrm{m}$ as a function of distance.

pacemaker replacement intervals The results of these calculations can be used to determine the lives saved by pacemakers with one replacement interval as compared with pacemakers with a different replacement period Results of these calculations are shown in Table 313 For example, for an equilibrium population of 10,000 pacemaker patients, the use of plutonium-powered pacemakers with an expected service life of 10 years would save, in 10 years, an estimated 373 lives (1100727) when compared with conventional pacemakers with a $1 \frac{1}{2}$ - to 3 -year service life The lives saved for other combinations of expected pacemaker service lives may be obtained from Table 313

Data for these computations were abstracted from literature references This literature represents experıence with approximately 20,000 patients with conventional-powered pacemakers The input data for the computation included (1) estimated mortality of pace maker patients from causes not pacemaker-related, (2) replacement of pacemakers due to battery depletion at a distribution of times over $1 \frac{1 / 2}{2}$ to 3 years as reported in the literature and at the other designated replacement intervals, (3) pacemaker replacements because of random falures at the rate of $2 \%$ annually for all types, (4) a patient mortality rate due to pacemaker system fallures of $01 \%$ annually, (5) mortalıty rates due to initial implantation surgery of $3 \%$ and due to reimplan. tation surgery of $1 \%$, and (6) the addition of new patients to the groups to replace patients lost from the groups by death

Pacemaker patient populations are not representative of the US populace with respect to age distribution The age distribution of patients submitted by Medtronics, Inc ${ }^{3}$ was used in this study since their data cover the largest statistical population of patients (1989 patients) and are similar to other reported age distributions

Each patient group was subdivided into five-year age subgroups The mortality rate from natural attrition for each age subgroup was assumed to be the same as the U S mortality rate for the subgroup The patient age distribution, US populace mortality rates and expected patıent deaths from natural attrition per age subgroup are presented in Table 314

3 Medtronics, Inc, "Benefits Resulting from the Use of the Isotopic Pulse Generator," Dec 17, 1973, with enclosure "Long-Term Survival of the Bearers of Cardiac Stımulators," Marie-Francoise LeFebvre, Attachee au Centre Hospitalier Regional de Lille, January 1963-July 1972 
Table 31.4. Pacemaker patient mortality estımates

From natural attrition Does not include pacemaker-related mortality

\begin{tabular}{ccccc}
\hline $\begin{array}{c}\text { Age } \\
\text { group }^{a}\end{array}$ & $\begin{array}{c}\text { Percent of } \\
\text { patients in } \\
\text { age group }\end{array}$ & $\begin{array}{c}\text { Percent of } \\
\text { Patient deaths } \\
\text { per year }^{c}\end{array}$ & $\begin{array}{c}\text { Average } \\
\text { remaining } \\
\text { lfetime } \\
\text { (years) }\end{array}$ & $\begin{array}{c}\text { Expected } \% \\
\text { patient deaths } \\
\text { per year }\end{array}$ \\
\hline $0-5$ & 016 & 244 & 710 & 0004 \\
$6-10$ & 016 & 021 & 672 & 00003 \\
$11-15$ & 016 & 020 & 623 & 00003 \\
$16-20$ & 017 & 056 & 575 & 00009 \\
$21-25$ & 015 & 071 & 528 & 00011 \\
$26-30$ & 015 & 069 & 481 & 00010 \\
$31-35$ & 025 & 083 & 435 & 00021 \\
$36-40$ & 025 & 119 & 388 & 00030 \\
$41-45$ & 145 & 178 & 343 & 00258 \\
$46-50$ & 145 & 262 & 299 & 00380 \\
$51-55$ & 44 & 388 & 257 & 01707 \\
$56-60$ & 44 & 561 & 218 & 02468 \\
$61-65$ & 155 & 775 & 181 & 12013 \\
$66-70$ & 155 & 1019 & 148 & 15795 \\
$71-75$ & 195 & 1278 & 118 & 24921 \\
$76-80$ & 195 & 1380 & 93 & 26910 \\
$81-85$ & 75 & 1394 & 70 & 10455 \\
$86-90$ & 75 & 3532 & 50 & 26490 \\
$81-95$ & 03 & 6895 & 50 & 02069 \\
96 up & 03 & 10000 & & 03000 \\
& & & & 1266 \\
\hline
\end{tabular}

\footnotetext{
${ }^{a}$ Mean patient age, 668 years

${ }^{b}$ Based on information from Medtronics, Inc, on age distribution of pacemaker patients

${ }^{c}$ Based on average U S mortality rate for each age group This assumes the life expectancy of pacemaker patients to be the same as the life expectancy of other persons of the same age
}

The patient population withın each subgroup was adjusted yearly in this computer study for 20 years These adjustments included subtracting yearly the total number of patient deaths in each group from the patient population of that age group and then promotıng an appropriate fraction of the remaining patients into the next older subgroups The total number of patient mortalities per age subgroup is a sum of patient deaths from natural attritions deaths due to risk of surgery, and deaths caused from pacemaker fallures

The above procedures for adjusting the patient populations yearly assume that pacemaker patient mortality rates due to natural attrition are the same as those of the US populace of the same ages This appears to be valid, for physicians have reported that many patients for whom pacemakers are implanted return to a relatively normal life, that is, to activities considered appropriate for their age, and they enjoy normal longevity patterns

\section{SUMMARY}

The medical benefits (reduction of patients' surgical risk of death, complications, pain, suffering, and anxiety) and the environmental risks (radiation exposure to the population and patients) of using plutonium-powered cardiac pacemakers are difficult to quantıfy on a basis that can be directly compared

For a pacemaker population of 10,000 patients plutonium-powered pacemakers with a 10 - to 20 -year service life would save six to nine lives annually when compared with conventional pacemakers with a 6 -year service life The total radiation exposure to the US population from 10,000 plutonium-powered pacemaker implants would be $258 \mathrm{man}$-rems/year Exposures to others from pacemakers implanted in patients accounts for 256 man-rems/year of this total, with approximately 2 man-rems resulting from postulated breaches of fuel capsules The total-body exposure to 10,000 patients will exceed 1000 man-rems/year, but this is a voluntary risk 
The NRC has not yet issued its final position on the use of plutonium-powered cardiac pacemakers There appears to be an alternative pacemaker, the rechargeable nickel-cadmium battery-powered pacemaker, which offers a postulated service lifetime similar to that of the plutonium-powered unit However, rechargeable pacemakers are not suitable for all patients requiring a long-lived pacemaker (Up to about 25\% of patients requiring pacemakers can fully use a unit's lifetıme of 10 to 20 years )
There is a small population of pacemaker patients which can benefit from the use of plutonium-powered cardiac pacemakers, and the benefits to these patients are substantially greater than the risks to the environment, which are comparatively small Future authorized use of these units will most likely be selective with respect to patients and subject to strict requirements on accountability, recovery, and disposal 